\title{
Communicative-and-pragmatic typology of directive speech acts in contemporary English elucidative utterance structure
}

\author{
M. V.Stasiv \\ Lviv Polytechnic National University, Lviv, Ukraine \\ Corresponding author. E-mail: stasiv_mariya@ukr.net
}

Paper received 29.03.18; Accepted for publication 05.04.18.

\section{https://doi.org/10.31174/SEND-Ph2018-160VI47-16}

\begin{abstract}
The article deals with the study of directive pragmatics of the elucidative speech act in the structure of utterance of elucidative type in modern English. The analysis has been conducted with regard to the pragmemic structure of the key illocutionary predicate of the principal clause of the research object. The specificity of the directive speech act formation in the analyzed utterance has been described. The communicative-and-pragmatic types of the directively targeted elucidative utterances have been distinguished.

Keywords: directive speech act, elucidative utterance-directive, communicative-and-pragmatic structure, key illocutionary predicate, pragmemic structure, communicative-and-pragmatic type of speech act.
\end{abstract}

Introduction. At the present stage of the linguistic science development, studies of the subjective factor functioning in the language, speech and communication are being actively conducted. The analysis of scientific information in this direction has shown an increased interest of linguists in the study of issues related to the research of speech act units in the communicative-and-pragmatic dimension. In this context, a thorough analysis of speech acts of directive type is important, which will make it possible to specify the orientation of speech actions of the speaker within the communicative situation of interaction.

Brief review of publications. The issue of the speech acts taxonomy with differentiation of such their type as the directive has been raised in many scientific works of Ukrainian and foreign linguists, who have chosen different principles and criteria as the basis of classification. The speech acts were differentiated on the basis of semantic meaning of (performative) verbs and the illocutionary functions of speech acts (J. L. Austin [11]; $\mathrm{Yu}$. D. Apresian [1]). The relations of participants in the communicative process were important in the typologization of speech acts (K. Bach [20; 21]). The determination of types of illocutionary acts was done by their correlation with the syntactic moods of verbs (J. van der Auwera [19]). The research used a comprehensive approach focused on the delineation of illocutionary acts in view of the syntactic-and-semantic features of each type and their behavior in the discourse (D. Wunderlich [30]). Linguists built the classification of illocutionary speech acts with the account of various distinctive features: purpose, expression of speaker's psychological state, etc. (J. R. Searle [15]); a way to achieve the illocutionary purpose, its intensity, etc. (D. Vanderveken [16]); institutionality, noninstitutionality, etc. (V. V. Bogdanov [5]). Context changes caused by speech acts were also taken into account in their division (Th. Ballmer [22]). The speech acts have been systematized by the semantic primitives of the meaning of speech act verbs (A. Wierzbicka [29]). Classification types of speech acts were determined depending on their role in the social-and-communicative interactions of communicants (G. Leech [26]). The key criterion for distinguishing the types of speech acts was the nature of the pragmatic component (communicative purpose) (G. G. Pocheptsov [12]). Consideration of speech acts within the various classes was based on the intention of the speaker to do an action (B. Fraser [24]). A classifica- tion of speech acts according to differential principles was highly appreciated in linguistics, for instance: source of experience, reference structure, focus (W. Stiles [28]). The type of speech act was identified in the light of cognitive "protocoling" of what the participants in the speech group said (F. S. Batsevych [3]). The intentional meaning of the performative and its illocutionary function has also become the key parameters for the delimitation of speech acts (N. I. Formanovska [18]).

Distinctive principles for identifying the directive type of speech acts served as the basis for linguistic studies of its pragmatic status and construction of the communicative-and-pragmatic system of utterances-directives of various types (A. V. Doroshenko [7], V. M. Arinshtein [2], O. I. Bieliaeva [4]; T. Kohnen [25]; V. H. Kulikova [10]; O. V. Yerofeieva [8]; A. N. Ismailova [9] et al.). Since English elucidative utterances of directive type were not considered within the speech act context and were not the subject of differentiation into communicative-andpragmatic subtypes, the analysis of these utterancesdirectives at the communicative-and-pragmatic level of their actualization is relevant.

The purpose of this essay is to conduct a thorough analysis of speech acts of directive type in the structure of elucidative utterances of contemporary English. The following tasks should be executed to achieve the purpose: determination of the essence of the speech act-directive, which is implemented within the English elucidative utterance; studying the communicative-and-pragmatic organization of the utterance of elucidative type with the directive orientation of the speech action; development of methodology for analyzing the research object at the communicative-and-pragmatic level of its actualization; distinguishing and description of the main communicative-and-pragmatic types of this speech act.

Materials and methods of research. The material of research is a collection of English elucidative utterancesdirectives found in the texts of the British National Corpus (a total of 8,414 utterances) [23].

The research of the communicative-and-pragmatic aspect of the English elucidative utterance was made in three stages with application of the intent analysis. At the initial stage, the pragmatic subtype of the elucidative utterance has been determined on the basis of the initial intentional meaning ("elucidative") of the elucidated key illocutionary predicate of the principal clause of elucida- 
tive utterance, for example: recommend; order; demand, etc. The next step was to identify the secondary type of intention - the coercive - in the analysis of the pragmatic subtype of the elucidated key illocutionary predicate, for example: recommend - coercive intention; order - coercive intention; demand - coercive intention, etc. The last stage of the research allowed distinguishing the elucidative utterances-directives according to the coercive type of intention, which lies in their basis and affects the meaning of the whole utterance within the speech act context, for instance: We recommend that you weigh yourself each day. The judge ordered that Paul Spencer, 17, and Alwyn Stephenson, 16, both of Stockwell, be detained for $41 / 2$ years. I demand that you turn her away, Neil.

Presentation of the main material and substantiation of the research results. The pragmatic directive is the basic element of the complex pragmatic hierarchy of speech acts (O. A. Romanov [13], O. A. Semeniuk [14], etc.). The directive speech act is traditionally considered as the expression of the speaker's will, which is aimed at the execution of action by the hearer (N. F. Hladush [6], O. S. Sklianchuk [17], etc.). The suggested study is based on J. Searle's typology of illocutionary acts: assertives, directives, commissives, expressives and declaratives [15, p. 170]. Among the analyzed elucidative utterances, we come across commissives, expressives, assertives and directives. We share the view that directive is a type of speech act, which expresses speaker's attempts to have the hearer do something [15, p. 182].

During the analysis of the communicative-andpragmatic structure of the elucidative utterance-directive, the limiting case of the elucidative speech act of directive type, it has been found that its key component is an elucidated key illocutionary predicate of its principal clause. The relation of the latter with the directive type of speech act is explicitly traced in their detailed pragmatic structuring $[27$, p. 31]. The microsenses of the key illocutionary predicate are formed on the basis of its core and peripheral semes. In the microsense context, the communicativeand-intentional sense is generated. A set of microsenses (pragmemic structure) of the key illocutionary predicate provides information about directive orientation of the elucidative utterance. This is evidenced by the coercive intention of the speaker, which is embodied in the pragmemic structure of the communicative-and-intentional sense, expressed at the language level, by the key illocutionary predicate. Coercive type of the speaker's intention and the situation in which its verbal implementation is carried out in the elucidative utterance, determine the communicative-and-pragmatic type of the speech actdirective.

The analysis of elucidative utterances of directive type in three stages showed that the coercive intention is embodied in the structure of the communicative-andintentional sense of the key illocutionary predicate. It is therefore appropriate to delineate the subtypes of elucidative utterances-directives by the pragmatics of this predicate.

To distinguish the communicative-and-pragmatic subtypes of the pragmatic directive of elucidative utterances, we study the pragmemic structure of 20 key illocutionary predicates: advise, argue, ask, demand, dictate, direct, hint, imply, insist, observe, order, propose, recommend, remember, request, see, suggest, teach, tell, warn.

The article presents the examples illustrating the process of analysis of the pragmemic structure of key illocutionary predicates and the most characteristic ways of forming the communicative-and-pragmatic structure of the whole elucidative utterance-directive.

Example 1. The communicative-and-pragmatic basis of the elucidative-type utterances can make the key illocutionary predicate see in imperative mood. This peculiarity is expressed directly in its semantic load to make sure that you do something or that something is done. Activation of the key sense link MAKING SURE has the communicative-and-intentional senses to assure oneself, to make certain of within the analyzed type of utterances. Complementation of microsense DOING "puts" the speaker's advice in the elucidative utterance, which is a message, suggestion or instructing to the hearer about the best behavior in a particular situation. In the microsense filling of the predicate being analyzed, the manifestation of the coercive intention of the speaker is meant. On the basis of the above, we include the elucidative utterance, which is a bearer of two communicative-and-intentional senses, in the communicative-and-pragmatic type of speech actsdirectives, for instance: See that they are well looked after, Davis. See that your child has everything for ski school: lift pass, ski school tickets, boots, skis, poles and money for a hot drink. See that you write or print out from your computer a clear explanation of each part of your analysis as you do it.

Example 2. The pragmatic directive can be expressed with the key illocutionary predicate teach in the assertive form. Its semantic load to make somebody feel or think in a different way makes it possible to distinguish the key microsense MAKING and the peripheral ones FEELING, THINKING and DIFFERENCE, which become relevant within the microcontext and form the communicativeand-intentional senses of training, instruction. Activation of the key microsense link in the principal clause of the elucidative utterance attracts the hearer to change of the world and prompts him/her to react to the sense of the utterance. The elucidative utterance is filled through the predicate being analyzed with the intention of coercion, the manifestation of which in its communicative-andpragmatic structure allows distinguishing a speech actdirective, for example: Christianity also teaches that man is a special creation, related but distinct from the animals, made in God's image and likeness. The Bible also teaches that God provides all men with certain common benefits - conscience, the recognition of right and wrong, and certain institutions (family, state, church) which encourage good and discourage evil. Tracy Kidder's story teaches that economic success comes through the talent, energy, and commitment of a team - through collective entrepreneurship.

The above examples show that the directive pragmatics of the utterance is due to the key directive in the principal clause, where the subordinate clause is only its constituent element. The key directive is expressed by: 1) pragmatic key illocutionary predicate in the imperative mood; 2) pragmatic key illocutionary predicate in the assertive form. 
In the study of the corpus of English elucidative utterances, the communicative-and-pragmatic types of speech acts-directives were identified, such as: demanding, discouraging from, making proposal, dictation (coercion, inducement), remembering, caution, remark, advising ((strong) requesting), suggesting, training, (official) ordering, insisting, hinting, to making certain of, assuring oneself, prompting, instruction, warning, advice, offering, requesting, recommending, disposing of something, assertion.

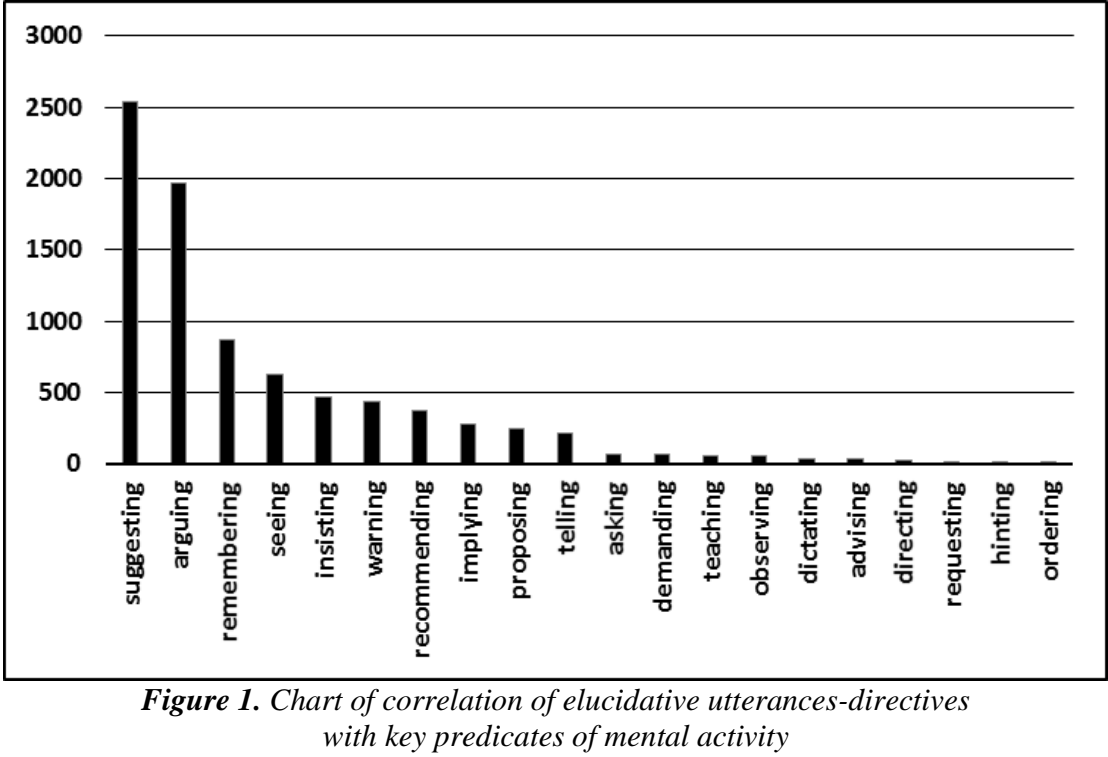

As a result of the analysis of 8414 elucidative utterances-directives, their quantitative ratio has been established. The obtained data show that the utterances with key illocutionary predicates suggest $(2536-30,14 \%)$, argue $(1969-23,4 \%)$, remember $(872-10,36 \%)$ and see $(628-7,46 \%)$ are more frequent than utterances, where the key components are the following predicates: insist $(465-5,53 \%)$, warn $(441-5,24 \%)$, recommend $(372-$ $4,42 \%)$, imply $(278-3,3 \%)$, propose $(252-3 \%)$, tell $(212-2,52 \%)$, ask $(67-0,8 \%)$, demand $(67-0,8 \%)$, teach $(58-0,69 \%)$, observe $(56-0,67 \%)$, dictate $(41-$ $0,49 \%)$, advise $(34-0,4 \%)$, direct $(27-0,32 \%)$, request $(17-0,2 \%)$, hint $(12-0,14 \%)$ and $\operatorname{order}(10-0,12 \%)$ (Figure 1).

Conclusions. To sum up, we should note that in the speech act context the directively oriented elucidative utterance is embodied in the elucidative speech act- directive, which is a communicative-and-pragmatic unit of speech activity, aimed at implementing a coercive intention in a communicative situation of interaction. The communicative-and-pragmatic structure of the research object is a combination of an elucidated key illocutionary predicate of the principal clause of the elucidative utterance and one or more elucidative illocutionary predicates of the subordinate clause of this utterance. The key illocutionary predicate is fundamental in determining the directive pragmatics of the elucidative utterance and distinguishing its communicative-and-pragmatic types.

Continuation and development of the lingvopragmatic research of utterances of elucidative type that implement other types of illocutionary functions in the speech act context is consider to be promising in terms of resolving in further scientific investigations.

\section{REFERENCES}

1. Apresian Yu. D. Performatives in grammar and dictionary / Yu. D. Apresian // Publ. AS USSR. Ser. lit. \& lang. - 1986. Vol. 45. - No. 3. - P. 208 - 223.

2. Arinshtein V. M. Legal awareness of society and "public directives" / V. M. Arinshtein // Studia linguistica. - SPb.: Education, 1995. - P. $75-94$.

3. Batsevych F. S. Fundamentals of communicative linguistics: [textbook] / F. S. Batsevych. - K.: Publ. center "Academia", 2004. -344 p.

4. Belyaeva E. I. Grammar and pragmatics of motivation. English language / E. I. Belyaeva. - Voronezh: Publ. VGU, 1992. $-168 \mathrm{p}$.

5. Bogdanov V. V. Verbal communication. Pragmatic and semantic aspects / V. V. Bogdanov. - L.: Publ. LGU, 1990. $88 \mathrm{p}$.

6. Gladush N. F. Narrative directives in contemporary English: Author's thesis for the scien. degree of Candidate of Philology: spec. 10.02.04 "Germanic languages" / N. F. Gladush. K., 1985. $-22 \mathrm{p}$.

7. Doroshenko A. V. Motivational speech acts and their interpretation in the text (based on the material of the English lan- guage): Author's thesis for the scien. degree of Candidate of Philology: spec. 10.02.04 "Germanic languages"/ A. V. Doroshenko. - M., 1986. - 18 p.

8. Yerofeeva Ye. V. Pragmatic realization of the category of motivation in the French discourse (on the example of speech acts of order and command) / Ye. V. Yerofeeva // Philological sciences. Questions of theory and practice. - Tambov: Gramota, 2014. - No.3 (33). - P.1. - P. 76 - 79.

9. Ismailova A. N. Ways of expressing motivation in the Korean language / A. N. Ismailova // Uchionyie zamietki TOGU. 2016. - T.7. - No.3 (2). - P. $168-170$.

10. Kulikova V. H. Structure of motivational speech acts of modern French language (communicative-and-pragmatic aspect): Author's thesis for the scien. degree of Candidate of Philology: spec. 10.02.05 "Romance languages" / V. H. Kulikova. - Kyiv, 2001. - 19 p.

11. Austin J. L. How to Do Things with Words / J. L. Austin // New in Foreign Linguistics. - M.: Progress, 1986. - Issue 17. Theory of speech acts. - P. $22-130$. 
12. Pocheptsov G. G. Sentence / G. G. Pocheptsov, I. P. Ivanova, V. V. Burlakova // Theoretical Grammar of Contemporary English Language. - M., 1981. - P. $161-281$.

13. Romanov A. A. System analysis of regulatory tools for dialogical communication / A. A. Romanov. - M.: Institute of Linguistics of the AS USSR, Kalininskiy SHI, 1988. - 183 p.

14. Semeniuk O. A. Fundamentals of speech communication theory: [textbook] / O. A. Semeniuk, V. Yu. Parashchuk. K.: VC "Academia", 2010. - 240 p.

15. Searle J. R. Classification of illocutionary acts / J. R. Searle // New in Foreign Linguistics. - M.: Progress, 1986. - Vol. 17. Theory of speech acts. - P. $170-194$.

16. Searle J. R. Basic concepts of speech acts calculus / J. R. Searle, D. Vanderveken // New in Foreign Linguistics. M.: Progress, 1986. - Vol. 18. Logical analysis of natural language. - P. $242-263$.

17. Sklianchuk O. S. Means of implementation of courtesy in modern English: Author's thesis for the scien. degree of Candidate of Philology: spec. 10.02.04 "Germanic languages" / O. S. Sklianchuk. - Kyiv, 1995. - 18 p.

18. Formanovskaya N. I. Speech interaction: communication and pragmatics / N. I. Formanovskaya. - M.: Publ. "IKAR", 2007. $-480 \mathrm{p}$

19. Auwera J. van der. On the Meaning of Basic Speech Acts / J. van der Auwera // Journal of Pragmatics. - 1980. - № 4. P. $253-264$.

20. Bach K. Linguistic Communication and Speech Acts / K. Bach, R. M. Harnish. - Cambridge (Mass.): Harper, 1980. $-327 \mathrm{p}$.

21. Bach K. Speech Acts and Pragmatics [Electronic resource] / K. Bach // Blackwell Guide to the Philosophy of Language. -
Wiley - Blackwell, 2003. - Mode of access to page: http://userwww.sfsu.edu/kbach/Spch.Prag.htm.

22. Ballmer Th. Speech Act Classification / Th. Ballmer, W. Brennenstuhl. - Berlin etc.: Mouton de Gruter, 1981. $274 \mathrm{p}$.

23. British National Corpus - XML Edition: XAIRA version 1.23 [Electronic resource]. - Published by OUCS on behalf of the BNC Consortium. - (14 GB). - Oxford, 2007. - 2 DVD. Requirements: Windows 2000/XP/Vista: DVD-ROM.

24. Fraser B. Hedged Performatives / B. Fraser // Syntax and Semantics. - New York etc.: Academic Press, 1975. - Vol. 3. Speech Acts. - P. $187-210$.

25. Kohnen T. Explicit performatives in Old English: A corpusbased study of directives / T. Kohnen // Journal of Historical Pragmatics. - 2000. - Vol. 1(2). - P. 301-321.

26. Leech G. N. Principles of Pragmatics / G. N. Leech. - London; New York: Longman, 1983. - $250 \mathrm{p}$.

27. Stasiv M. V. Micropragmatics of language code units (based on the analysis of elusidative speech acts selected from BNC) / M. V. Stasiv // Science and Education a New Dimension. Philology. - Budapest: Society for Cultural and Scientific Progress in Central and Eastern Europe, 2015. - Vol. III (11), Is. 56. - P. $30-33$.

28. Stiles W. Classification of Intersubjective Illocutionary Acts / W. Stiles // Language in Society. - 1981. - Vol. 10. P. $227-249$.

29. Wierzbicka A. English Speech Act Verbs: A Semantic Dictionary / A. Wierzbicka. - London, etc.: CUP, 1987. - 500 p.

30. Wunderlich D. Studien zur Sprechakttheorie D. Wunderlich. - Frankfurt/M.: Suhrkampf, 1976. - 417 p.

Коммуникативно-прагматическая типология директивных речевых актов в структуре изъяснительных высказываний современного английского языка

М. В. Стасив

Аннотация. В статье исследуется директивная прагматика изъяснительного речевого акта в структуре высказывания изъяснительного типа в современном английском языке. Анализ проведен с учетом прагмемной структуры опорной иллокутивной предикативной единицы главной части объекта исследования. Описывается специфика формирования директивного речевого акта в этом высказывании. Выделяются коммуникативно-прагматические типы директивно направленных изъяснительных высказываний.

Ключевые слова: директивный речевой акт, изъяснительное высказывание-директив, коммуникативно-прагматическая структура, опорная иллокутивная предикативная единица, прагмемная структура, коммуникативно-прагматический тип речевого акта. 